\begin{tabular}{lcl}
\hline & A N N A L E S \\
UNIVERSITATIS & MARIAE CURIE-SKŁODOWSKA \\
LUBLIN - POLONIA & \\
VOL. XLVIII, 4 & SECTIO H & 2014 \\
\hline & Związek Banków Polskich
\end{tabular}

MARIUSZ ZYGIEREWICZ

Dylematy zmian instytucjonalnych $w$ polskim sektorze banków spółdzielczych $w$ świetle nowych europejskich regulacji nadzorczych oraz wyników ekonomicznych sektora

Dilemma of institutional transformation of Polish cooperative bank sector in face of new prudential regulations for banks in Europe and economic results of cooperative banks in Poland

Słowa kluczowe: banki, banki spółdzielcze, regulacje ostrożnościowe

Keywords: banks, associated banks, prudential regulation

\title{
Wstęp
}

Sektor banków spółdzielczych w Polsce staje obecnie przed jednym z największych wyzwań dotyczących sposobu prowadzenia działalności w najbliższym okresie. Uchwalenie w Unii Europejskiej pakietu nowych regulacji ostrożnościowych oraz wyraźne pogorszenie wyników finansowych sektora banków spółdzielczych w 2013 r. spowodowały, że podmioty te muszą podjąć zasadniczą decyzję dotyczącą sposobu prowadzenia biznesu bankowego w przyszłości. Nie ulega bowiem wątpliwości, że uwarunkowania prawne nie pozwalają na kontynuowanie działalności tego sektora w dotychczasowej formie zrzeszeń banków spółdzielczych, a sytuacja ekonomiczna banków powinna dodatkowo motywować je do podejmowania odważnych kroków, z uwzględnieniem ich długotrwałych skutków finansowych. Skala faktycznych zmian instytucjonalnych będzie jednak w dużym stopniu wynikać także z gotowości samych banków do rozpoczęcia wspólnych działań na rzecz umocnienia pozycji sektora bankowości spółdzielczej na rynku usług finansowych w Polsce. Demokratyczny 
ustrój kraju pozwala bowiem na funkcjonowanie dwóch modeli, które będą możliwe do zaakceptowania przez banki spółdzielcze.

Artykuł został podzielony na trzy zasadnicze części. W pierwszej z nich skoncentrowano uwagę na bezpośrednich uwarunkowaniach regulacyjnych, które wymuszają wprowadzenie zmian instytucjonalnych. W drugiej przedstawiono generalną ocenę wyników ekonomicznych banków w ostatnich latach ze wskazaniem najważniejszych wpływających na nie czynników. W części trzeciej zaprezentowano główne formy zmian instytucjonalnych $\mathrm{w}$ bankowości spółdzielczej możliwe do zrealizowania $\mathrm{w}$ istniejących uwarunkowaniach prawnych oraz dokonano analizy szans i wyzwań, jakie zdaniem autora wiążą się z wyborem każdego z tych wariantów. Na tej podstawie w zakończeniu została podjęta próba wskazania optymalnego rozwiązania systemowego dla polskich banków spółdzielczych.

\section{Uwarunkowania regulacyjne}

Ostatni kryzys na światowych rynkach finansowych spowodował olbrzymi wzrost aktywności regulatorów, dążących do poprawy stabilności funkcjonowania tychże rynków. Takie wysiłki były i są podejmowane w skali globalnej (przy dużej aktywności Rady Stabilności Finansowej, Bazylejskiego Komitetu Nadzorców Bankowych, Rady Międzynarodowych Standardów Rachunkowości), na szczeblu unijnym (dyrektywy i rozporządzenia Rady i Parlamentu Europejskiego oraz wytyczne Europejskich Władz Nadzoru Bankowego - EBA, i Europejskiego Banku Centralnego) oraz krajowym.

Spośród licznych nowych regulacji unijnych największe znaczenie dla działalności banków w Europie ma pakiet określany mianem CRD IV, obejmujący dyrektywę 2013/36/UE z dnia 26 czerwca 2013 r. w sprawie warunków dopuszczenia instytucji kredytowych do działalności oraz nadzoru ostrożnościowego nad instytucjami kredytowymi i firmami inwestycyjnymi [Dz. Urz. UE nr L 176] oraz rozporządzenie 575/2013 z dnia 26 czerwca 2013 r. w sprawie wymogów ostrożnościowych dla instytucji kredytowych i firm inwestycyjnych [Dz. Urz. UE nr L 176], zwane też rozporządzeniem CRR. Z punktu widzenia działalności banków spółdzielczych w Polsce, a szerzej ujmując - dotychczasowych zrzeszeń banków spółdzielczych, najistotniejszą rolę będą odgrywać rozporządzenie w części poświęconej nałożeniu na instytucje kredytowe nowych wymogów w zakresie spełnienia norm płynności oraz zapisy dotyczące zaliczania udziałów banków spółdzielczych do funduszy podstawowych. $\mathrm{W}$ tym artykule uwaga zostanie skoncentrowana wyłącznie na pierwszym $\mathrm{z}$ tych zagadnień, gdyż uznano, że pozostałe tematy wymagają odrębnej, szerszej analizy.

Nowe unijne normy płynności, wchodzące stopniowo w życie od 2015 r., generalnie nie muszą stanowić wielkiego wyzwania dla większości banków działających w Polsce, przynajmniej w odniesieniu do normy płynności krótkoterminowej. Banki w Polsce mają bowiem od 2009 r. obowiązek przestrzegać ilościowych norm płynności określonych przez lokalny nadzór bankowy. Jednak specyficzna konstrukcja 
normy płynności krótkoterminowej przyjętej w regulacji europejskiej powoduje, że banki nie mogą dłużej stosować dotychczasowego modelu rozwoju polegającego na finansowaniu znacznej części swojej działalności ze środków finansowych pochodzących z rynku międzybankowego. Uznano bowiem, że zarówno z punktu widzenia stabilności pozyskiwanych przez banki środków finansowych, jak i ryzyka zarażenia się trudnościami ekonomicznymi kolejnych banków w okresie kryzysu celowe jest stworzenie regulacji, która wymuszałaby szersze oparcie działalności banków na środkach obcych, pochodzących z depozytów klientów i przedsiębiorstw kosztem pozyskiwania depozytów z rynku międzybankowego. Rozstrzygają o tym art. 421 i 422 wspomnianego rozporządzenia. Pierwszy z nich ustanawia bardzo niską wagę odpływu dla przyjętych depozytów detalicznych (5\% lub $10 \%$ ), drugi ustala wyższą wagę odpływu dla przedsiębiorstw (20\% lub 40\%) i wysoką, de facto sankcyjną wagę dla depozytów od innych instytucji kredytowych (100\%).

To jedno rozwiązanie powoduje, że system zrzeszeń banków spółdzielczych w Polsce nie może dłużej funkcjonować w dotychczasowym kształcie. W ramach zrzeszenia banki spółdzielcze pozyskują środki finansowe od klientów w formie depozytów, a niewykorzystane nadwyżki lokują w banku zrzeszającym. Jednocześnie bank zrzeszający, prowadząc działalność bankową w ograniczonej skali i dążąc do niekonkurowania ze zrzeszonymi bankami spółdzielczymi, nie prowadził dotychczas aktywnej polityki w zakresie pozyskiwania depozytów od klientów niefinansowych, zwłaszcza detalicznych, traktowanych preferencyjnie w rozporządzeniu 575/2013, na potrzeby wypełnienia normy płynności. W konsekwencji wejście nowych wymogów ostrożnościowych spowoduje, że banki zrzeszające banki spółdzielcze nie będą w stanie przestrzegać normy płynności, funkcjonując w obecnym kształcie. Jednocześnie rozpoczęcie działalności depozytowej przez banki zrzeszające byłoby bardzo trudne, gdyż oznaczałoby diametralną zmianę profilu tych banków. W dzisiejszych warunkach nie są one dobrze przygotowane do masowego pozyskiwania klientów detalicznych, chociażby z powodu skromnej sieci placówek bankowych oraz braku odpowiedniego systemu informatycznego. Specyfika banków zrzeszających polega też bardziej na pełnieniu funkcji usługowej, pomocniczej dla banków spółdzielczych, a nie na prowadzeniu działalności konkurencyjnej względem nich. Kontynuacja dzisiejszego sposobu funkcjonowania i niespełnienie wymogów regulacyjnych przez banki zrzeszające będą stanowić podstawę do zastosowania odpowiednich sankcji wobec nich ze strony nadzoru bankowego.

W tych uwarunkowaniach historycznych działania zrzeszeń banków spółdzielczych należy zatem poszukiwać możliwości spełnienia norm płynności przy wykorzystaniu rozwiązań regulacyjnych zawartych w rozporządzeniu 575/2013. Wymieniony już wcześniej art. 422 wymienia dwa warianty:

1) obniżenie wagi odpływu do $25 \%$ w przypadku depozytów złożonych przez członka tego samego systemu ochrony instytucjonalnej (ust. 3),

2) zastosowanie niższego współczynnika procentowego odpływu w indywidualnych przypadkach na podstawie zezwolenia wydanego przez właściwy organ 
w przypadku, gdy deponent jest instytucją centralną lub członkiem sieci zgodnie $\mathrm{z}$ art. 400 ust. 2 (ust. 8).

Głównie w tych dwóch kierunkach należy zatem wprowadzać możliwe zmiany instytucjonalne, które z jednej strony mogą pozwolić na zachowanie dotychczasowej idei wspólnego działania banków spółdzielczych w ramach zrzeszeń, a z drugiej na spełnienie regulacyjnej normy ostrożnego działania. Te kierunki analizy tym bardziej zasługują na rozważenie, że część z tych rozwiązań jest także preferencyjnie traktowana $\mathrm{w}$ innych regulacjach, zarówno w rozporządzeniu, jak i w niektórych dyrektywach (np. dyrektywie o systemie gwarantowania depozytów czy dyrektywie ustanawiającej ramy na potrzeby prowadzenia działań naprawczych oraz restrukturyzacji i uporządkowanej likwidacji w odniesieniu do instytucji kredytowych i firm inwestycyjnych).

\section{Ekonomiczne uwarunkowania zmian instytucjonalnych w bankowości spółdzielczej}

W 2013 r. w sektorze banków spółdzielczych odnotowano zauważalne pogorszenie wyników finansowych w stosunku do roku poprzedniego oraz w relacji do lat wcześniejszych. Tak silnej negatywnej zmiany nie zaobserwowano w sektorze banków komercyjnych. Główną przyczynę słabszych wyników finansowych banków spółdzielczych stanowiły obniżenie się rynkowych stóp procentowych oraz wysoka nierównowaga przyrostu kwoty należności od klientów z sektora niefinansowego i zobowiązań wobec tego sektora. Obniżenie rynkowych stóp procentowych było następstwem redukcji oficjalnych stóp procentowych przez Narodowy Bank Polski w związku ze spadkiem tempa inflacji i spowolnieniem rozwoju gospodarczego. Te zmiany spowodowały wyraźny spadek zysków banków spółdzielczych, gdyż zdecydowaną przewagę $\mathrm{w}$ dochodach tej grupy banków stanowiły tradycyjnie dochody odsetkowe, oparte na relatywnie wyższej marży odsetkowej niż stosowana w sektorze banków komercyjnych. Wzrost konkurencji na rynku bankowym, w tym dążenie wielu banków do pozyskiwania większej liczby depozytów długoterminowych, oraz spadek rynkowych stóp procentowych spowodowały wyraźne obniżenie się marży odsetkowej. W 2013 r. wyniosła ona 3,5\%, podczas gdy w poprzednich kilkunastu latach nigdy nie spadła poniżej 4\%, a w 2012 r. było to ponad 4,3\%. Warto także pamiętać, że marża ta w bankowości spółdzielczej jeszcze w 2000 r. o 4 p.p. przewyższała tę w bankach komercyjnych, a w 2013 r. ta różnica zmniejszyła się do ok. 1 p.p.

Obniżka stopy redyskonta weksli w NBP spowodowała także ograniczenie dopłat do oprocentowania kredytów preferencyjnych udzielanych na cele rolnicze, które w przypadku wielu mniejszych banków spółdzielczych były zasadniczym obszarem działalności bankowej oraz istotnym źródłem dochodów.

Rosnąca nierównowaga $\mathrm{w}$ zakresie przyrostu kwoty należności od klientów $\mathrm{z}$ sektora niefinansowego i zobowiązań od tego sektora wynikała natomiast z dwóch 
zasadniczych przyczyn. Po pierwsze, banki spółdzielcze mają strukturalne trudności z dotarciem do wielu potencjalnych klientów, często na skutek węższej oferty usług oraz ograniczonego terenu działania. Na przykład w bankach spółdzielczych skala wzrostu należności z tytułu kredytów mieszkaniowych była w ostatnich latach relatywnie nieduża, podczas gdy w komercyjnych stanowiła ona główne źródło wzrostu aktywów banków. Ponadto spowolnienie gospodarcze w kraju wpływało na mniejsze zainteresowanie klientów kredytem bankowym. Po drugie, doświadczenia licznej grupy banków spółdzielczych pokazały, że duży wzrost akcji kredytowej w ostatnich latach, także w okresie spowolnienia gospodarczego, spowodował wyraźne pogorszenie jakości aktywów od klientów niefinansowych. W zakresie kredytów dla klientów indywidualnych udział kredytów o obniżonej jakości wzrósł z 3,3\% w 2009 r. do $4,8 \% \mathrm{w} 2013 \mathrm{r}$. W przypadku przedsiębiorstw była to zmiana odpowiednio z $8 \%$ do $10 \%$. Skutek stanowiły wysokie rezerwy celowe, co wpływało na pogorszenie wyników finansowych.

Nawet znaczne ograniczenie kosztów działania banków spółdzielczych - po raz pierwszy w historii były one w 2013 r. niższe niż rok wcześniej - nie mogło odwrócić negatywnego trendu. Wynik finansowy netto tych podmiotów obniżył się w okresie tylko jednego roku aż o blisko 25\% i nominalnie zbliżył się do poziomu z $2010 \mathrm{r}$. Jednak wówczas aktywa banków były o 37\% mniejsze niż na koniec 2013 r. Te wyniki pokazują, na jakie trudności napotykają banki spółdzielcze przy niskich stopach procentowych, musząc podejmować wysiłki na rzecz pozyskania nowych klientów. Zmianę wyników banków spółdzielczych można też skonfrontować z rezultatami podmiotów komercyjnych, którym w 2013 r. udało się, co prawda z trudem, ale utrzymać dobre wyniki finansowe z roku poprzedniego (wzrost o 0,5\%). Oczywiście w następnym roku banki komercyjne również mogą mieć problemy z utrzymaniem dobrych wyników, ale przedstawione wyżej czynniki będą rzutować też na wyniki finansowe banków spółdzielczych w najbliższych latach.

Środki finansowe niewykorzystane przez banki spółdzielcze na rozwój akcji kredytowej były w większości lokowane w bankach zrzeszających, które jednak także musiały zmienić swoją politykę stóp procentowych oferowanych w odniesieniu do depozytów pozyskiwanych od banków spółdzielczych. Zgodnie z raportem Komisji Nadzoru Finansowego oceniającym sytuację ekonomiczną sektora bankowego w 2013 r., w latach 2010-2012 banki zrzeszające, pod presją konieczności wypłat wysokiego oprocentowania bankom zrzeszonym za złożone depozyty oraz wypłaty dywidendy, angażowały się w ekspozycje o wysokim stopniu ryzyka. W II kwartale 2013 r. nastąpiło zmniejszenie kwoty depozytów banków spółdzielczych z powodu obniżenia ich oprocentowania. Wpłynęło to na zmniejszenie dochodów odsetkowych banków spółdzielczych [Informacja UKNF, 2014, s. 4-5, 19, 29].

Równocześnie dość sceptycznie można ocenić działalność biznesową banków zrzeszających. W dużym stopniu jest to wynikiem ich specyficznego umiejscowienia w systemie bankowości spółdzielczej, ale niekiedy także błędów popełnianych w zakresie identyfikacji kierunków ekspansji banków. W efekcie rozmiary akcji kre- 
dytowej cechują się dużą zmiennością w zależności od wielkości dopływu środków finansowych z banków spółdzielczych, a wiele środków jest lokowanych na rynku międzybankowym ze względu na szybkość realizacji takiego rozwiązania. Można się też zastanawiać, czy budowany przez banki zrzeszające portfel kredytowy jest racjonalny, ale jednocześnie trzeba pamiętać o ograniczonej sieci oddziałów oraz dążeniu do niekonkurowania $\mathrm{z}$ bankami spółdzielczymi.

W konsekwencji wyniki finansowe banków zrzeszających ulegały corocznie wyraźnemu pogorszeniu w ostatnich latach. Jeszcze w 2010 r. łączny wynik finansowy netto banków zrzeszających wyniósł 114,3 $\mathrm{mln}$ zł, rok później było to $81,7 \mathrm{mln}$ zł, a w 2012 r. już tylko 37,1 mln zł. W ostatnim roku zsumowany wynik finansowy obu banków zrzeszających okazał się już ujemny ( $-117 \mathrm{mln}$ zł). Zwrot na aktywach i na kapitale był w bankach zrzeszających zdecydowanie niższy niż średni wynik w bankach spółdzielczych [Informacja UKNF, 2014, s. 28, 45, 48, 75]. W 2013 r. obniżył się też wyraźnie współczynnik wypłacalności w tej części sektora bankowego (z $10,1 \%$ do $7,3 \%$ ), do poziomu niższego niż minimalne wymagania regulacyjne nałożone na banki.

Powyższe wyniki, przedstawione w sposób bardzo skrócony, pokazują konieczność zmiany modelu biznesowego w polskiej bankowości spółdzielczej. Powinna ona polegać na dążeniu do stworzenia równowagi między utrzymaniem autonomii sprzedażowej banków spółdzielczych a większą integracją biznesową w ramach grupy, obejmującą m.in. określenie wspólnych standardów działania, nowych usług bankowych i wspólnych rozwiązań technologicznych. W tym ujęciu banki spółdzielcze powinny w większym stopniu skoncentrować uwagę na celach biznesowych, sprzedażowych, polegając w większym stopniu na wsparciu banków zrzeszających w zakresie zarządzania, ale także w przygotowaniu bardziej wyrafinowanych usług finansowych. Rozwój regulacji w sektorze bankowym będzie bowiem powodować, że samodzielne wypełnianie wszystkich funkcji zarządczych w małych bankach będzie generować koszty niewspółmiernie wysokie do wyników osiąganych ze sprzedaży usług klientom niefinansowym. Małe banki spółdzielcze nie będą także w stanie przygotować ani zaoferować szerokiej gamy usług finansowych, do których klienci będą uzyskiwali coraz łatwiejszy dostęp w miarę globalizacji oraz informatyzacji gospodarki.

\section{Możliwe formy zmian instytucjonalnych w bankowości spóldzielczej w Polsce}

Istniejące uwarunkowania regulacyjne, a do pewnego stopnia także ekonomiczne tworzą silne przesłanki do poszukiwania nowych kierunków funkcjonowania sieci bankowości spółdzielczej. Wśród potencjalnych form przekształceń w sektorze banków spółdzielczych można wyróżnić co najmniej cztery zasadnicze rozwiązania: 
1) samodzielna działalność banków spółdzielczych,

2) zbudowanie sieci banków spółdzielczych bez żadnego z istniejących obecnie banków zrzeszających,

3) utworzenie systemu ochrony instytucjonalnej,

4) powołanie zrzeszenia zintegrowanego.

Zasadne jest zatem przeanalizowanie zalet i wad poszczególnych modeli i zastanowienie się, który z nich może okazać się najefektywniejszy w sektorze banków spółdzielczych w Polsce.

\subsection{Samodzielne funkcjonowanie banków spóldzielczych}

Samodzielne funkcjonowanie banków spółdzielczych może być rozwiązaniem możliwym do zastosowania tylko dla relatywnie niewielkiej ich grupy. Aby móc działać poza siecią bankowości spółdzielczej, bank musi bowiem spełnić wszystkie warunki regulacyjne przewidziane dla funkcjonowania banku w Polsce. Trzeba pamiętać, że na mocy Ustawy Prawo bankowe banki spółdzielcze działające w zrzeszeniu mają obniżone wymogi regulacyjne (np. w zakresie minimalnego poziomu funduszy własnych istnieje wymóg $1 \mathrm{mln}$ euro zamiast $5 \mathrm{mln}$ euro). Zgodnie z informacją KNF na koniec 2013 r. tylko 118 banków spółdzielczych (spośród 571 istniejących) miało fundusze własne większe niż $5 \mathrm{mln}$ euro. To oznacza, że zdecydowana większość z nich nie może zastosować tego wariantu i musi nadal działać w zrzeszeniu. Ponadto każdy z banków funkcjonujących samodzielnie będzie musiał spełniać wszystkie wymogi ostrożnościowe, w tym w zakresie wypełniania norm płynności.

To rozwiązanie nie jest preferowane przez polski nadzór bankowy, gdyż wystąpienie ze zrzeszeń największych banków spółdzielczych wyraźnie osłabi siłę i potencjał istniejących zrzeszeń. Banki opuszczające zrzeszenia będą zainteresowane odprzedażą posiadanych akcji w banku zrzeszającym, a to właśnie one z racji swojej wielkości są największymi akcjonariuszami banków zrzeszających. Wyjście części banków będzie oznaczać także wycofanie ich zaangażowania finansowego w formie depozytów w banku zrzeszającym. Skutki takich ruchów w przypadku rozpoczęcia samodzielnej działalności przez wiele banków spółdzielczych mogłyby silnie zdestabilizować sytuację banków zrzeszających i zrzeszeń. Dlatego też KNF stara się zniechęcić kierownictwa banków do podejmowania prób działania poza zrzeszeniem. Wśród możliwych posunięć wymienia się m.in. wprowadzenie zasady kadencyjności, zgodnie z którą te same osoby mogłyby pełnić swoje funkcje tylko przez dwie kadencje (maksymalnie 10 lat).

Niezależnie od skutków ekonomicznych wynikających z opuszczenia zrzeszenia przez część banków spółdzielczych warto również zauważyć, że samodzielne funkcjonowanie banków spółdzielczych może wiązać się z poważnymi wyzwaniami charakterystycznymi dla małych banków komercyjnych na rynku finansowym. Nie ulega bowiem wątpliwości, że te podmioty będą małymi, jednymi z najmniejszych 
instytucji bankowych działających na stopniowo konsolidującym się polskim rynku usług bankowych. Samodzielne funkcjonowanie będzie oznaczać konieczność spełnienia wszystkich wymogów regulacyjnych, ponoszenie kosztów z tym związanych przy jednoczesnym ograniczonym zakresie usług oferowanych klientom i kosztach wynikających z wejścia na nowy rynek. Doświadczenia ostatnich lat pokazują, że nie wszystkim największym bankom spółdzielczym, które podjęły próbę szybkiego rozwoju, udało się osiągnąć pełny sukces. Wiele z nich uzyskuje relatywnie nie najlepsze wyniki finansowe, co w dużym stopniu wynika z kosztu przyciągnięcia nowych klientów i pozyskania finansowania. Według raportu KNF za 2013 r. 7 największych banków spółdzielczych odnotowało spadek wyniku finansowego aż o 45,7\% w skali roku, a poziom ich ROE i wskaźnika C/I nie jest imponujący [Informacja UKNF, 2014, s. 26-28]. W wielu bankach poziom adekwatności kapitałowej nieznacznie tylko przekraczaa minimalne standardy i jest on znacznie niższy od rekomendowanego przez nadzór bankowy. Spółdzielczy charakter banku utrudnia proces pozyskania nowego kapitału w drodze emisji na rynku kapitałowym.

\subsection{Zrzeszenie banków spółdzielczych z wyłączeniem dotychczasowych banków zrzeszających}

Drugim możliwym rozwiązaniem jest stworzenie zrzeszenia wyłącznie na bazie istniejących banków spółdzielczych, z wyłączeniem udziału w nim dotychczasowych banków zrzeszających. Ta koncepcja pojawiła się jako skutek prawdopodobnej konieczności zacieśnienia współpracy między bankami w ramach zrzeszenia po wprowadzeniu zmian regulacyjnych zgodnie z rozporządzeniem 575/2013, w tym możliwego nałożenia na banki obowiązku udzielania wsparcia finansowego uczestnikowi w złej sytuacji ekonomicznej przez pozostałych uczestników zrzeszenia. Stosowanie takiej zasady solidarności wymusza zwracanie przez uczestników większej uwagi na kondycję finansową pozostałych potencjalnych członków zrzeszenia banków działającego w nowej formule. W efekcie szczególnie bacznie obserwowana jest sytuacja finansowa banku zrzeszającego, gdyż będzie on z pewnością największym członkiem zrzeszenia i ewentualna konieczność udzielenia mu wsparcia może stanowić bardzo duże obciążenie dla pozostałych uczestników zrzeszenia. Trzeba pamiętać, że przedstawione wyżej aktualne wyniki finansowe obu banków zrzeszających nie są najlepsze. Ta sytuacja wzmacnia presję na poszukiwanie dróg tworzenia zrzeszenia z pominięciem dotychczasowych banków zrzeszających.

Utworzenie zrzeszenia poprzez przekształcenie w bank zrzeszający jednego z obecnych banków spółdzielczych może nieść ze sobą wiele wyzwań, niektóre z nich będą zbliżone do tych związanych z podjęciem samodzielnej działalności przez największe banki spółdzielcze. Nowa struktura będzie bowiem oznaczać pozostawienie banków zrzeszających z ich problemami i kontynuowanie wspólnej działalności tylko przez część banków spółdzielczych, niekiedy będących w gorszej sytuacji ekonomicznej. Może to powodować powstanie problemu o charakterze systemowym w tej części 
bankowości spółdzielczej i pogłębić trudności z restrukturyzacją pozostałej części tego sektora.

Stworzenie nowej struktury zrzeszeniowej będzie też oznaczać poważne wyzwanie dla jej uczestników. Żaden z dotychczasowych banków spółdzielczych nie ma bowiem doświadczenia w prowadzeniu działalności apeksowej na rzecz innych banków, brak będzie wartości dodanej dla banków spółdzielczych wynikającej z istnienia takiego banku zrzeszającego, a poziom kapitałów własnych zdecydowanej większości banków spółdzielczych będzie zapewne niewystarczający, aby któryś z nich mógł realnie pełnić funkcję banku zrzeszającego. Takiemu bankowi zrzeszającemu trudno będzie przedstawić bankom spółdzielczym ofertę bardziej złożonych usług bankowych, a skala ewentualnego wsparcia finansowego dla banku będącego przejściowo w złej sytuacji ekonomicznej także może być ograniczona. Do tego należy dodać wszystkie trudności organizacyjne związane z tworzeniem nowej struktury organizacyjnej w zrzeszeniu. W bankowości spółdzielczej ten proces niemal zawsze jest trudniejszy niż w bankowości komercyjnej, która wyraźniej opiera się na sile kapitału. W konsekwencji trudno znaleźć mocne argumenty i wymienić korzyści systemowe tworzenia zrzeszenia bez udziału dotychczasowych banków zrzeszających. Najpoważniejszą korzyścią krótkoterminową, bardziej o charakterze partykularnym dla wybranych banków spółdzielczych, może być ograniczenie skali ewentualnej pomocy finansowej na sanację działającego banku zrzeszającego. Trudno jednak uznać a priori, że nowy bank zrzeszający będzie bardziej efektywny, skoro to banki spółdzielcze są wyłącznymi właścicielami istniejących dziś banków zrzeszających i dotąd nie udało im się prawidłowo wypełnić funkcji właścicielskiej wobec banku zrzeszającego. Nie ma żadnych silnych przesłanek, które miałyby wskazywać, że tym razem historia potoczy się innymi torami, niż miało to miejsce w przeszłości.

\subsection{Utworzenie systemu ochrony instytucjonalnej}

System ochrony instytucjonalnej (Institutional Protection Scheme - IPS) stanowi rozwiązanie preferowane przez regulatora europejskiego dla sektora banków spółdzielczych i jest jedynym wyraźnie imiennie nazwanym i zdefiniowanym, przynajmniej w najważniejszych zarysach, w rozporządzeniu 575/2013. Graniczne cechy systemu ochrony instytucjonalnej zostały określone w art. 113 ust. 7 rozporządzenia i stanowią one, iż:

1) może być on utworzony dla instytucji objętych odpowiednimi wymogami ostrożnościowymi,

2) instytucje mają siedzibę w tym samym kraju,

3) nie występują przeszkody dla szybkiego transferu funduszy własnych lub spłaty należności na rzecz podmiotu,

4) istnieją gwarancje, że IPS jest w stanie udzielić niezbędnego wsparcia $\mathrm{z}$ funduszy, do których ma łatwy dostęp, 
5) IPS ma odpowiednie i jednakowo zorganizowane mechanizmy monitorowania i klasyfikowania ryzyka, co daje całościowy przegląd sytuacji ryzyka wszystkich członków oraz IPS,

6) IPS zapewnia własny przegląd ryzyka,

7) IPS sporządza skonsolidowane sprawozdanie lub sprawozdanie obejmujące zagregowany bilans, rachunek zysków i strat, sprawozdanie na temat sytuacji i ryzyka,

8) IPS ma co najmniej 24-miesięczny okres wypowiedzenia,

9) wyklucza się wielokrotne wykorzystanie tych samych składników do obliczania funduszy własnych,

10) w IPS duży udział mają instytucje o zasadniczo jednolitym profilu działalności,

11) adekwatność mechanizmów monitorowania ryzyka i przeglądu ryzyka podlega zatwierdzeniu przez właściwy organ.

Te warunki zostały określone $\mathrm{w}$ wielu przypadkach bardzo nieprecyzyjnie. $\mathrm{Na}$ przykład zaznaczono, że system ochrony instytucjonalnej ma mieć odpowiednie i jednakowo zorganizowane mechanizmy monitorowania i klasyfikowania ryzyka, które dają całościowy przegląd sytuacji ryzyka wszystkich członków oraz systemu. Ta definicja może oznaczać zarówno daleko idącą unifikację rozwiązań w postaci np. jednolitych procedur udzielania kredytów, oceny zdolności kredytowej u wszystkich uczestników zrzeszenia, jak i wykorzystanie podejścia bardziej zdecentralizowanego, polegającego np. na stosowaniu wyłącznie tych samych zasad klasyfikacji należności pod względem ich jakości. Interpretacja może być zatem bardzo różna i to od niej będzie zależeć poziom unifikacji w zakresie ewentualnego pozbawienia poszczególnych uczestników systemu niezależności w prowadzeniu biznesu bankowego.

Celem działania systemu ochrony instytucjonalnej jest generalnie udzielanie sobie wzajemnych gwarancji płynności i wypłacalności wszystkich uczestników systemu, tak aby nie dopuścić do ich niewypłacalności. Wsparcie odbywa się za pomocą określonych mechanizmów, przy czym musi zostać udzielone, ale IPS może wcześniej zażądać opracowania programu naprawczego przez uczestnika systemu. Jednocześnie z powodu istnienia wzajemnych gwarancji nie można wypowiedzieć żadnemu podmiotowi członkostwa w przypadku pogorszenia się sytuacji podmiotu w okresie krótszym niż 24-miesięczny. Organom IPS przyznano kompetencje sprawowania kontroli wewnętrznej uczestników oraz stosowania sankcji wobec nich.

Funkcjonowanie w ramach systemu ochrony instytucjonalnej daje bankom szereg istotnych przywilejów regulacyjnych, pozwalających na złagodzenie niektórych norm bezpiecznego działania. Wśród nich należy wymienić zwłaszcza:

1) zastosowanie wagi odpływu $25 \%$ dla obliczenia normy płynności krótkoterminowej (LCR) w odniesieniu do depozytów przyjętych od innych uczestników systemu ochrony instytucjonalnej,

2) stosowanie wagi ryzyka $0 \% \mathrm{w}$ stosunku do zaangażowania kredytowego wobec kontrahenta będącego członkiem tego samego systemu ochrony instytucjonalnej,

3) zniesienie limitu zaangażowania kapitałowego 10\% wobec innych członków IPS, 
4) możliwość zastosowania niższej stawki do wpłat wnoszonych na system gwarantowania depozytów,

5) możliwość wykorzystania niższej stawki w zakresie wpłat wnoszonych na system uporządkowanej likwidacji banku (resolution regime),

6) możliwość obniżenia opłat wnoszonych z tytułu pokrycia kosztów funkcjonowania nadzoru bankowego.

Istnienie gwarancji w ramach systemu ochrony instytucjonalnej oznacza potencjalne poważne zobowiązania finansowe, które będą musieli ponieść członkowie IPS, aby ratować podmiot znajdujący się w kłopotach. Oczywiście gdy system działa prawidłowo, efektywnie funkcjonuje system wczesnego monitorowania zagrożeń i kontroli, to prawdopodobieństwo powstania takich zobowiązań jest niewielkie.

Stworzenie systemu ochrony instytucjonalnej powoduje konieczność zebrania znacznych środków finansowych na szybkie wsparcie uczestników systemu. Mają one charakter zarówno obowiązkowych depozytów utrzymywanych $\mathrm{w}$ jednym z podmiotów systemu (dla wsparcia płynności), jak i środków zgromadzonych na specjalnym funduszu pomocowym (dla wsparcia wypłacalności). Skala niezbędnych środków nie została określona przez regulatora. Nie ulega jednak wątpliwości, że wobec niewielkiego zasobu zebranych dotychczas środków finansowych będzie to dla uczestników systemu wyzwanie. Trzeba również mieć świadomość, że stworzenie odpowiedniego systemu monitoringu zarządzania ryzykiem, bezpieczeństwem systemu, czyli infrastruktury, będzie wymagać poniesienia niebagatelnych kosztów. W tym systemie wewnętrzna kontrola zastępuje w istotnym stopniu działania nadzoru bankowego.

Powołanie systemu ochrony instytucjonalnej rodzi kolejne wyzwania w zakresie funkcjonowania tego ciała i wszystkich jego uczestników. Wymaga ono określenia akceptowalnego dla wszystkich podmiotów poziomu niezależności funkcjonowania poszczególnych instytucji $\mathrm{w}$ prowadzeniu biznesu, ustanowienia możliwego do przyjęcia przez wszystkich poziomu ryzyka. Istnienie systemu powinno też służyć budowie poczucia silniejszej więzi między wszystkimi jego członkami.

Skuteczność sprawowania wewnętrznej kontroli i nakładania sankcji staje się kwestią kluczową, gdyż w przeciwnym razie może pojawić się ryzyko rozmycia odpowiedzialności, wykorzystywania przez słabszych uczestników udzielonych im gwarancji i wymuszania pomocy od podmiotów będących w lepszej sytuacji, lepiej zarządzających ryzykiem. Powstaje zatem pytanie, czy zakres gwarancji płynności i wypłacalności ma być nieograniczony, a jeśli tak, to czy system kontroli może zminimalizować powyższe ryzyko.

Zbudowanie systemu monitoringu i kontroli rodzi konieczność powołania odpowiednich struktur organizacyjnych. Specyficzne relacje między wszystkimi podmiotami, w tym między bankiem zrzeszającym i bankami spółdzielczymi, mogą powodować konieczność powołania nowych organów w zrzeszeniu, komplikując strukturę zrzeszenia banków spółdzielczych. Szczegóły tych rozwiązań nie zostały nigdzie uregulowane ani wypracowane w polskich zrzeszeniach banków spółdzielczych. Być może dopiero przyszły wzór umowy określi dokładne ramy funkcjonowania systemu. 
Dziś wydaje się, że są one zbyt ogólne, aby można było mówić o wszystkich zaletach i wadach tego rozwiązania.

System ochrony instytucjonalnej może nieść wiele korzyści jej uczestnikom. Przede wszystkim daje silne gwarancje istnienia wszystkich podmiotów. Ta zaleta musi być jednak powiązana $\mathrm{z}$ inną cechą - umiejętnością dyscyplinowania członków IPS i rozwiązywania problemu na wczesnym etapie jego powstania. System umożliwia także osiągnięcie korzyści regulacyjnych przewidzianych w regulacjach unijnych. W zakresie biznesowym zbudowanie jednego modelu zarządzania ryzykiem może pozwolić na stworzenie wspólnego modelu biznesowego, który pozwoli wykorzystać efekt skali dla całego IPS i dla poszczególnych jego członków, przyczyniając się do zwiększenia zakresu oferowanych usług bankowych i redukcji kosztów.

\subsection{Model zintegrowany}

Koncepcja tego modelu została pierwszy raz przedstawiona przez Komisję Nadzoru Finansowego w 2013 r. jako rozwiązanie pośrednie na drodze do budowy systemu ochrony instytucjonalnej [Analiza UKNF, 2013, s. 20-23]. Aktualnie polski nadzorca bankowy nie popiera już tego modelu, ale jest on poważnie rozważany jako preferowane rozwiązanie przez znaczną część banków spółdzielczych.

Nie został on ściśle zdefiniowany w regulacjach ostrożnościowych, chociaż podstawę prawną jego istnienia zawarto w art. 422 ust. 8 rozporządzenia 575/2013 (deponent jest instytucją centralną lub członkiem sieci zgodnie z art. 400 ust. 2 lit. d) CRR). Ten ostatni artykuł stanowi o składnikach aktywów będących należnościami od regionalnych lub centralnych instytucji kredytowych, z którymi dana instytucja jest stowarzyszona $\mathrm{w}$ sieci zgodnie z przepisami prawnymi lub ustawowymi i które na mocy tych przepisów są odpowiedzialne za rozliczenie środków pieniężnych $\mathrm{w}$ ramach sieci, definiując $\mathrm{w}$ ten sposób zakres podmiotowy stosowania tego wariantu.

Przesłankę zastosowania modelu zintegrowanego stanowi zwiększenie bezpieczeństwa i stabilności finansowej zrzeszenia i jego członków. Zakłada on wspieranie płynności i wypłacalności uczestników poprzez wykorzystanie tworzonych depozytów obowiązkowych i funduszu pomocowego, a więc instrumentów używanych także w systemie ochrony instytucjonalnej. Jednak w modelu zintegrowanym brak nieograniczonych gwarancji płynności i wypłacalności. Górną granicę zaangażowania zrzeszenia stanowią zobowiązania z tytułu przyznanej pomocy określonej w umowie i wielkość utworzonego funduszu pomocowego. Udzielenie wsparcia bankowi na utrzymanie wypłacalności może być uzależnione od spełnienia określonych przesłanek, np. przyjęcia i realizacji programu naprawczego. Jednak w przeciwieństwie do systemu ochrony instytucjonalnej w tym modelu władze zrzeszenia nie mają możliwości nałożenia sankcji na uczestnika. W zrzeszeniu prowadzone są kontrola 
i monitoring zgodności działalności uczestników z przepisami prawa, umowami, statutami uczestników, ale kompetencje nadzorcze pozostają wyłącznie w nadzorze bankowym.

Ten system przewiduje zatem niższy poziom solidaryzmu niż w IPS i powoduje większe trudności w kontrolowaniu prawidłowości funkcjonowania modelu. Tym samym większę znaczenie ma dbałość poszczególnych członków o bezpieczeństwo swojego działania i mniejsze jest ryzyko wystąpienia zjawiska moral hazard, czyli podejmowania ryzykownej działalności w przeświadczeniu, że w przypadku poniesienia strat inni uczestnicy zrzeszenia przyjdą zawsze z pomocą.

Innymi słowy, model zintegrowany stanowi próbę pogodzenia niezależności uczestników systemu z jednoczesnym nałożeniem obowiązku ponoszenia wspólnych nakładów na utrzymanie ich płynności i wypłacalności oraz wdrożenia wspólnych zasad zarządzania płynnością. W porównaniu do systemu ochrony instytucjonalnej zakłada się zachowanie wysokiej niezależności banków spółdzielczych, ale jednocześnie mniejszą możliwość uzyskania wsparcia. Skala zmian w stosunku do obecnego modelu zrzeszenia jest zdecydowanie mniejsza niż w systemie ochrony instytucjonalnej.

To rozwiązanie nie wymaga ponoszenia wysokich nakładów na tworzenie nowych struktur organizacyjnych w zrzeszeniu. Kontrola wewnętrzna pozostaje w gestii poszczególnych banków spółdzielczych. Mniejszy solidaryzm w ramach zrzeszenia pozwala ograniczyć obciążenia uczestników na funkcjonowanie modelu. Jednocześnie skala potencjalnych preferencji regulacyjnych dla uczestników tego modelu jest zdecydowanie mniejsza niż w IPS. Rozporządzenie 575/2013 przewiduje jedynie możliwość zastosowania niższej wagi odpływu dla obliczania normy płynności krótkoterminowej od depozytów pozyskanych przez bank od innych członków modelu. Waga ta może wynosić 25-100\%, ale to właściwy organ (czyli lokalny nadzór bankowy) określa szczegółowo wysokość wagi odpływu. Uznaje się bowiem, że w sytuacji, gdy deponent należy do sieci, można oczekiwać niższego odpływu środków z depozytu w ciągu 30 dni, zwłaszcza gdy deponent stosuje ostrożny szacunek przypływu środków finansowych z tytułu wycofania depozytu złożonego u innego uczestnika zrzeszenia.

Właściwie nie przewiduje się innych korzyści regulacyjnych dla uczestników modelu zintegrowanego. Istnieje jeszcze tylko możliwość ubiegania się o wyłączenie w drodze zezwolenia wzajemnych ekspozycji uczestników z limitu ekspozycji kredytowych zgodnie z zapisami CRR. Nie ma natomiast regulacji pozwalających wprost na obniżenie obciążeń na system gwarantowania depozytów czy system uporządkowanej likwidacji banków, choć zapisy o zmniejszeniu opłat dla podmiotów generujących niższe ryzyko dają pewną możliwość redukcji takich kosztów.

Dużą wadą tego rozwiązania jest niejasność rozmiaru preferencji regulacyjnej w zakresie normy płynności. Zależy ona od poziomu odpływu ustalonego przez nadzór bankowy. Jeśli zastosowana waga odpływu będzie bliższa 100\% (tj. zasad ogólnych) niż 25\% (stosowana w IPS), będzie to oznaczać konieczność utrzymywania w banku zrzeszającym większego depozytu obowiązkowego przez banki spółdzielcze i tym 
samym będą one mogły mniej środków finansowych przeznaczać na rozwój akcji kredytowej. Niektóre szacunki pokazują, że depozyt obowiązkowy może wynosić nawet ok. 50\% środków finansowych pozyskanych przez bank spółdzielczy. Określenie zaś wagi odpływu na poziomie bliższym $25 \%$ automatycznie ogranicza koszty funkcjonowania modelu zintegrowanego.

Można przyjąć, że model ten nie powoduje istotnych zmian jakościowych w zakresie modelu biznesowego realizowanego przez zrzeszenie w stosunku do obecnych rozwiązań, a więc nie przynosi w tym zakresie uczestnikom dodatkowych korzyści, które wynikałyby z poprawy konkurencyjności działania banków spółdzielczych.

\section{Zakończenie}

Bankowość spółdzielcza w Polsce po raz kolejny w swojej najnowszej historii staje przed poważnym wyzwaniem regulacyjnym i biznesowym. Decyzje z $2013 \mathrm{r}$. dotyczące modelu funkcjonowania banków spółdzielczych mogą wywierać skutki przez wiele lat i decydować o możliwościach rozwoju tej części sektora bankowego. Banki spółdzielcze mają właściwie dwie opcje: stworzenie systemu ochrony instytucjonalnej oraz modelu zintegrowanego. Pozostałe rozwiązania są dostępne tylko dla nielicznych banków.

Pierwszy z wymienionych wariantów zakłada większą integrację sektora, pozbawienie banków spółdzielczych części ich dotychczasowej niezależności, zmusza do poniesienia kosztów tworzenia nowej struktury, a z drugiej strony pozwala na zastosowanie preferencji regulacyjnych oraz lepsze wykorzystanie potencjału ekonomicznego wspólnie działających podmiotów. Trzeba jednak zaznaczyć, że tego potencjału nie udało się wykorzystać dotychczas, mimo że struktura zrzeszeń nie przeszkadzała w osiągnięciu tego celu. Natomiast model zintegrowany może utrwalać strukturę bankowości spółdzielczej w obecnym kształcie, nie dając wielkich nadziei na zmianę jakościową prowadzenia biznesu, a przy niekorzystnych rozwiązaniach regulacyjnych może to być konstrukcja bardzo kosztowna.

Wybór optymalnych przekształceń strukturalnych w bankowości spółdzielczej bardzo komplikują niejasny kształt regulacji bankowych oraz zróżnicowanie sytuacji banków spółdzielczych działających w Polsce. Co do pierwszej z wymienionych trudności to mimo uchwalenia rozporządzenia 575/2013 wiele kwestii szczegółowych, niezwykle ważnych dla banków, będzie musiało zostać uregulowanych w innych aktach prawnych (ustawa, akty delegowane, umowa zrzeszenia) i dopiero ich opublikowanie pozwoli interesariuszom zdobyć pełniejszą wiedzę na temat korzyści i wad poszczególnych rozwiązań. Natomiast w kontekście drugiej kwestii trzeba nadmienić, że coraz wyraźniejszy podział banków spółdzielczych na podmioty duże i małe, na bardziej i mniej dynamicznie rozwijające swoją działalność biznesową będzie utrudniał podejmowanie wspólnych decyzji i prowadził do 
napięć w tym środowisku. Jednak banki nie będą mogły uniknąć podjęcia finalnej decyzji. Wiele czynników, w tym także rosnąca konkurencja ze strony banków komercyjnych, wydaje się przemawiać za wyborem rozsądnego systemu ochrony instytucjonalnej. Możliwe jednak, że w Polsce będą mogły być realizowane oba modele. Dziś funkcjonują bowiem dwa zrzeszenia banków spółdzielczych i każde z nich może podjąć decyzję o wyborze innego wariantu i wówczas każdy bank spółdzielczy będzie zdecydować, które rozwiązanie jest dla niego korzystniejsze.

\section{Bibliografia}

1. Analiza sytuacji bankowego sektora spółdzielczego, w tym funduszy własnych, w 2012 r. oraz informacja o przebiegu prac nad możliwymi modelami działania zrzeszeń w kontekście Dyrektywy CRD IV oraz Rozporządzenia CRR, Urząd Komisji Nadzoru Finansowego, Warszawa, czerwiec 2013.

2. Docelowy model bankowości spółdzielczej, „Zeszyty BRE Bank - CASE” 1998, nr 38.

3. Informacja o sytuacji banków spółdzielczych i zrzeszających w 2013 r., Urząd Komisji Nadzoru Finansowego, Warszawa, kwiecień 2014.

4. Mironczuk T., Szansa dla spółdzielców w Polsce, ,Rzeczpospolita”, 27.05. 2014.

5. Projekt ustawy o zmianie ustawy o funkcjonowaniu banków spółdzielczych, ich zrzeszaniu się i bankach spółdzielczych oraz ustawy - Prawo bankowe, http://legislacja.rcl.gov.pl (dostęp: 25.05.2014).

6. Pruski J., Model biznesowy banków spółdzielczych na tle nowych wymogów regulacyjnych, prezentacja na VI Forum Liderów Banków Spółdzielczych, 10.09.2013.

7. Rozporządzenie Parlamentu Europejskiego i Rady nr 575/2013 w sprawie wymogów ostrożnościowych dla instytucji kredytowych i firm inwestycyjnych, zmieniające rozporządzenie nr 648/2012 (Dz. Urz. UE L 176, poz. 1).

8. Swacha Cz., Wyzwania bankowości spółdzielczej wynikające z nowych regulacji nadzorczych i wdrażania IPS, Warszawa 2014, http://alterum.pl (dostęp: 02.06.2014).

9. Wspótczesna bankowość spótdzielcza, A. Szelągowska (red.), CeDeWu, Warszawa 2012.

\section{Dilemma of institutional transformation of Polish cooperative bank sector in face of new prudential regulations for banks in Europe and economic results of cooperative banks in Poland}

New prudential regulations established for banks in Europe (directive 2013/36/UE - known also as CRD IV and regulation 575/2013 - CRR) do not take into account the specific legal situation of cooperative bank sectors in different countries in sufficient way. This situation is particularly uncomfortable for sectors in those countries where associated cooperative banks are independent bodies with limited impact of associating bank on activity of associated banks. New prudential regulations oblige banks to change their internal structure and relationship. Additionally, the weaker economic results of cooperative banks in Poland in 2013 should be also an important driver of change. The main topic of the article is the presentation of different forms of possible institutional transformation in the Polish sector of cooperative banks and the analysis of advantages and disadvantages of each form of cooperation. The main solution can be an integrated model with weaker forms of cooperation or setting up the Institutional Protection Scheme model. Each of them generates important consequences for cooperative 
Pobrane z czasopisma Annales $\mathrm{H}$ - Oeconomia http://oeconomia.annales.umcs.pl Data: 26/04/2023 04:07:20

banks and for the associating bank. The biggest cooperative banks have also the third possibility - to act as fully independent institution, outside association with any bank. It is difficult to indicate one best solution for all banks, because the economic situation of banks is different and all national regulation concerning cooperative banks is not yet adopted. 